\begin{tabular}{|c|c|}
\hline$\exists$ & $\begin{array}{c}\text { International Journal of Current Research } \\
\text { and Academic Review }\end{array}$ \\
\hline $\begin{array}{ll}\mathrm{NT} \\
\mathrm{RS}\end{array}$ & $\begin{array}{c}\text { ISSN: 2347-3215 (Online),;Volume 5,; Number } 5 \text { (May-2017) } \\
\text { Journal homepage: http://www.ijcrar.com }\end{array}$ \\
\hline
\end{tabular}

doi: https://doi.org/10.20546/ijcrar.2017.505.016

\title{
A Study on the Aminoacid Composition of Different Algae Isolated From Echoor Lake, Kancheepuram District, Tamil Nadu, India
}

\author{
R. Murali ${ }^{\text {** }}$ and T. M. Vijayalakshmi ${ }^{2}$ \\ ${ }^{I}$ Department of Botany, Government Arts College for Men, Nandanam, Chennai 600 035, Tamil Nadu, India \\ ${ }^{2}$ Department of Medical Biochemistry, University of Madras, Taramani Campus, Chennai 600 113, Tamil Nadu, \\ India
}

*Corresponding author

\begin{tabular}{|c|c|}
\hline Abstract & Article Info \\
\hline \multirow{3}{*}{$\begin{array}{l}\text { The present study was made to investigate the aminoacid composition of six } \\
\text { freshwater algae namely, Chlamydomonas pertusa, Chlorella vulgaris, } \\
\text { Spirulina maxima, Spirogyra porticalis, Euglena sanguinea and Anabena } \\
\text { affinis collected from lake situated in Echoor village, near Sriperumudur, } \\
\text { Kancheepuram district, Tamilnadu, India. The aminoacids present in the algal } \\
\text { samples were extracted and estimated using automated aminoacid analyser. } \\
\text { The results have shown the presence of the following aminoacids in Leu, Lys, } \\
\text { Ile, Phe, Val, His, Arg, Met, Trp, Thr minute amounts in the screened algal } \\
\text { species. Among the tested species Spirulina maxima is found to have an } \\
\text { appreciable amounts of all these amino acids when compared to the rest of the } \\
\text { algal species. }\end{array}$} & $\begin{array}{l}\text { Accepted: } 28 \text { March } 2017 \\
\text { Available Online: } 20 \text { May } 2017\end{array}$ \\
\hline & Keywords \\
\hline & $\begin{array}{l}\text { Aminoacid Composition, } \\
\text { Algae, } \\
\text { Chlorella and Spirulina, } \\
\text { Chlamydomonas } \\
\text { Echoor Lake, } \\
\text { Kancheepuram District }\end{array}$ \\
\hline
\end{tabular}

\section{Introduction}

Microalgal species of Chlorella and Spirulina are being produced commercially for their good quality protein content and are being used in food and feed (Becker 2007).

Algae contribute to the nutrition of their animal hosts in two ways; firstly the animals are provided with the photo synthetically derived carbon, secondly nitrogen recycling is achieved by algae through the assimilation of animal derived nitrogenous waste compounds into compounds especially amino acids which enter again into animal tissues.
Essential amino acid translocation from the symbiotic algae to the animal host is a core process in the symbiotic nitrogen fixation. This is a special feature of algal cells and varies from that of the animal cells which cannot perform photosynthesis and cannot synthesize essential amino acids (Leu,Lys, Ile, Phe, Val, His, Arg, Met, Trp, Thr). Amino acid composition determines the protein quality of algae which may be employed in the development of new foods or additives for human and animal consumption. The current study is aimed to assess the amino acid composition of certain selected algal species that were isolated from a natural water body and that was grown in a medium enriched with a nitrogen 
source, namely urea for providing the maximum possible nitrogen to the cells.

\section{Materials and Methods}

The algal samples were collected from the lake situated in Echoor village, near Sriperumudur, Kancheepuram district, Tamilnadu, India. Certain identified species namely Chlamydomonas sp., Chlorella sp., Anabena sp., spirogyra sp., spirulina sp., and euglena sp., were isolated from the water samples. Amino acid analysis was performed with $2 \mathrm{~g}$ of dried respective algal species which were boiled in a refluxed condenser with $200 \mathrm{ml}$ of $6 \mathrm{~N}$ Hydrochloric acid for 24 hours. Hydrochloric acid is evaporated.50-70 $\mathrm{ml}$ of water is added to the remaining thick paste. The solution is neutralized and diluted to a suitable volume and filtered. For the determination of tryptophan, hydrolysis is carried out by autoclaving with $4 \mathrm{~N}$-sodium hydroxide for 16 hours (at 15 pound pressure).This sample is injected into the automated amino acid analyzer.

\section{Results and Discussion}

Protein is the most expensive macronutrient in ecologic and economic terms and therefore the one requiring the most attention with respect to sustainability (Swanson, 2013).Preliminary studies suggest that algal species may be practical alternatives to traditional protein and supplemental amino acid sources in foods. Safety, bioavailability, palatability and source variability of alternative items as food ingredients should be investigated prior to incorporation into supplemented foods. The present study shows that the levels of the tested amino acids were quite variable between the different species. The amino acid compositions of the isolated Spirulina sp., were quite richer in leucine, and had high levels of all the tested amino acids. This is followed by isolated Chlorella sp., then by the isolated Chlamydomonas sp. The amino-acid compositions were compared with those of standard reference protein rich foods (egg, soya, fish, milk, meat).Study of the amino acid profile of these six green algae, has shown that five amino acids occurred in high concentration in all of them. These were lysine, phenylalanine, isoleucine, tryptophan, and arginine. Histidine is the least in all the tested species. The results are tabulated in table 1.

Amino acid profile of different algae as compared with conventional protein sources and the WHO/FAO reference pattern (g per 100 protein), reveal that the levels of the essential amino acids in the microalgae were either similar to or greater than the levels of the same amino acids in the reference foods which are given in table 2, thus indicating a high protein quality for all micro algal species (Becker (2007), Fabregas and Herrero (1985).

Table.1 Amino acid profile of the tested algal species

\begin{tabular}{|l|l|l|l|l|l|l|l|l|l|l|}
\hline Algal Species & Ile & Leu & Val & Lys & Met & Phe & Thr & Trp & Arg & His \\
\hline Chlamydomonas sp., & 0.296 & 0.112 & 0.125 & 0.541 & 0.368 & 0.919 & 0.847 & 0.598 & 0.013 & 0.007 \\
\hline Chlorella $s p$ & 0.297 & 0.102 & 4.258 & 0.698 & 0.985 & 1.568 & 0.987 & 0.548 & 0.013 & 0.006 \\
\hline Spirulina $s p$ & 3.550 & 7.734 & 5.258 & 4.355 & 1.564 & 2.565 & 4.991 & 1.66 & 5.542 & 1.520 \\
\hline Spirogyra $s p$ & 0.219 & 0.598 & 0.558 & 0.585 & 0.367 & 0.568 & 0.589 & 0.515 & 0.884 & 0.454 \\
\hline Anabena $s p$ & 0.198 & 0.185 & 0.598 & 0.562 & 0.598 & 0.254 & 0.255 & 0.522 & 0.265 & 0.854 \\
\hline Euglena sp., & 0.255 & 0.154 & 0.158 & 0.252 & 0.549 & 0.958 & 0.215 & 0.588 & 0.582 & 0.876 \\
\hline & \multicolumn{9}{|l|}{ Values expressed as g \% } \\
\hline
\end{tabular}

Table.2 Amino acid Profile of with conventional protein sources

\begin{tabular}{|l|l|l|l|l|l|l|l|l|l|l|}
\hline Name of the source & Ile & Leu & Val & Lys & Met & Phe & Thr & Trp & Arg & His \\
\hline Egg & 4 & 8 & 7 & 5 & 3 & 6 & 2 & 1 & 6 & 2 \\
\hline Meat & 4 & 7 & 5 & 5 & - & 5 & 2 & 1 & 6 & 3 \\
\hline Fish & 2 & 4 & 5 & 7 & 2 & 4 & 1 & - & 6 & 2 \\
\hline Milk & 5 & 9 & 2 & 4 & 2 & 5 & 2 & 1 & 3 & 1 \\
\hline Soyabean & 4 & 7 & 5 & 8 & 2 & 4 & 4 & 7 & 7 & 1 \\
\hline
\end{tabular}


Earlier nutritional studies of microalgae as foods and feeds have shown that algal proteins are of high quality, comparable to conventional vegetable proteins in terms of their content of essential amino acids, which mainly determine the nutritional quality of a protein source. Little information is available on the nutritional value of algal proteins. Amino acid compositions of protein isolates in the algal species studied are favorable with FAO standards as is evidenced from the comparison made with the traditional protein rich dietary sources.

Amino acid composition determines the protein quality of algae. The results reveal that the levels of the essential amino acids in the microalgae were either similar to or greater than the levels of the same amino acids in the reference foods, thus indicating a high protein quality for all tested micro algal species in the current study. Hence along with the standard growth conditions supplementations are recommended to obtain the maximum possible production of biomolecules. Production costs may further be reduced by using mass culture. The algal species may be thus be employed in the development of new foods or additives for human and animal consumption after performing clinical trial experiments. The food value of the tested algae may be used to cope with the future food shortages.

\section{References}

Becker EW. 2004. Microalgae in human and animal nutrition. In: Richmond A., editor. Handbook of Microalgae Culture. Biotechnology and Applied Phycology. Oxford: Blackwell Science.

Becker EW. 2007. Microalgae as a source of protein. Biotechnology Advances 25: 207-210.

Fabregas J and Herrero C. 1985. Marine Microalgae as a potential source of single cell protein (SCP). Appl. Microbiol. Biotechnol. 23: 110-113.

Fowden, L., 1951. Aminoacids of certain algae. Nature 167, 1031,

Swanson KS, Carter RA, Yount TP, et al., (2013) Nutritional sustainability of pet food. Adv Nutr 4, $141-150$.

\section{How to cite this article:}

Murali R. and Vijayalakshmi T. M. 2017. A Study on the Aminoacid Composition of Different Algae Isolated From Echoor Lake, Kancheepuram District, Tamil Nadu, India. Int.J.Curr.Res.Aca.Rev. 5(5), 111-113.

doi: https://doi.org/10.20546/ijcrar.2017.505.016 